\title{
IAMJ
}

INTERNATIONAL AYURVEDIC MEDICAL JOURNAL

\section{CHATURMAS UPAVAS (FASTING) - A SCIENTIFIC REVIEW}

\author{
$\underline{\text { Jaybhaye Sulakshana }}^{1} \underline{\text { Zerikunthe Swapna }}^{2}$ Kendre Manchak $^{3}$
}

${ }^{1}$ Professor, Department of Swasthavritta,

${ }^{2}$ Assistant Professor, Department of Swasthavritta,

${ }^{3}$ Professor, Department of Kayachikitsa, S.G. Patel Ayurveda Hospital and Research Center, New Vallabha Vidya Nagar, Anand, Gujarat - 388121, India

Corresponding Author: brahmi29@gmail.com

\section{https://doi.org/10.46607/iamj3108092020}

(Published online: September 2020)

Open Access

(C) International Ayurvedic Medical Journal, India 2020

Article Received: 23/08/2020 - Peer Reviewed: 09/09/2020 - Accepted for Publication: 09/09/2020

D) Check for updates

\section{ABSTRACT}

Chaturmas Upvas is as old as human being. Maharshi Vyas transcribed first time regarding various rituals. Chaturmas means four months. It is a holy period from July to October. Upvas is withdrawal of senses from materialistic world as well as going back from misconduct and living quality life at all level. It is practiced for spiritual upgrading as well as to worship the God. It is 'willful refrainment from eating all or some kind of food or drink or total abstinence from all kinds of food for definite period of time' but it is much more than simply not eating, it is for overall well-being and to acquire divine grace. It contributes in purification of body as well as mind and improves overall health which is mainstay of Dharma, Artha, Kama and Moksha for which human is supposed to borne. In this article, Chaturmas Upvas and its contribution in physical, spiritual and mental health is reviewed scientifically.

Keywords: Chaturmas, Upavas, Chaturmas Upvas, fasting etc.

\section{INTRODUCTION}

Balanced state of Dosha, Agni, Dhatu, Malakriya and Prasanna Atma, Indriya as well as Mana is considered as health ${ }^{[1]}$. It is concerned at physical, spiritual, mental as well as social level. Physical health is possible by healthy lifestyle and natural food. Spiritual health can be accomplished by following Veda, Upanishad, exact rituals and festivals etc. Mental health may be a product of physical and spiritual health. Human life is 
considered for Dharma, Artha, Kama and Moksha which depends upon health. ${ }^{[2]}$ Scientific rituals as well as festivals are designed to contribute to health.

\section{Chaturmas}

The Sanskrit word Chaturmas is combination of Chatur (four) and Mas (month). It is a holy period of four months (July to October), beginning on Deva Shayani Ekadashi [The eleventh day of the first bright half, Shukla Paksha, of Ashadh (fourth month of the Hindu lunar calendar)] up to Deva Prabodhini Ekadashi [The eleventh day of the first bright half of Kartik (eighth month of the Hindu lunar calendar)]. The first month of Chaturmas is Shravan (Hindu lunar month) which is dedicated to Lord Shiva, especially the Mondays. Important festivals like Rakshabandhan, Nagpanchami, Janmashtami, Bendur (Pola) are celebrated in this month. The second month is Bhadrapad in which famous festival Ganesh Chaturthi is celebrated as well as in the dark fortnight Mahalayshraddha (rituals to appease departed ancestors and subtle bodies) is carried out. Distinguished festivals like Durga Puja, Navratri, Sharad Purnima and Dashehara are celebrated in Ashwin month. Dipavali festival is celebrated in Kartika which is last month of Chaturmas. ${ }^{[3]}$ As per Vishnupuran and Garudpuran, during Chaturmas Lord Vishnu is in Yoga Nidra with demon king Bali in Sutallok.

\section{Upvasa}

The Sanskrit word Upvasa is combination of Upa (close to) and Vas (to dwell). Hence living like god and close to god is Upvasa. It is withdrawal of senses from materialistic world. In Purana and epic history, Upvasa means going back from misconduct and living quality life at all level. It is as old as human being. It is practiced in Bharat (India) since ancient time by sages for their spiritual upgrading. It is also practiced by religious peoples to worship the God. Fasting is defined as 'willful refrainment from eating all or some kind of food or drink or total abstinence from all kinds of food for definite period of time' but it is much more than simply not eating, it is for overall well-being and to acquire divine grace. It contributes to purification of body as well as mind and improves overall health. [5]

\section{Scientific method of Chaturmas upvasa}

Chaturmas is for going back from misconduct and living quality life at all level. Atmachintan, Parmatma Chintan, worship to God Vishnu and Shiv, Mantra chanting, Maun Vritta (Silence), holy river bath, good conducts etc. are practiced in Chaturmas. Eating particular variety of healthy food once in a day. Food should be taken probably up to $1 \mathrm{pm}$ after praying God. Abstaining from Onion, Garlic, Brinjal, black gram, leafy vegetables, meat, alcohol drinking, travelling etc., which are not good for health during Chaturmas. ${ }^{[6]}$

\section{Today's pattern of Chaturmas upvasa}

Worship to God and puja is completed as a part of Chaturmas effort but not from inner level. Full heavy meal is taken in afternoon. In evening or in-between majority humans are commonly practicing tasty food which gives short pleasure to tongue and mind like fried food, Shabudana Vada, Bhagar Dosa, Rajgeera Thepla, Bhagar, Potato Samosa, Bhagar Sabudana Kachori, Potato patis, Bhagar Dhokla, Potato chips, Banana chips, Potato Papadi, Bhagar Papadi, Sabudana Papadi, Farali Chivada, Ice-cream etc. These are not healthy during Chaturmas.

\section{Need of Chaturmas Upvas}

In materialistic world human is trapped in vicious cycle hence his lifestyle is significantly changed. Sitting job, genetically modified and processed food, frequent consumption, over eating, ingestion without hunger sensation, improper methods of intake, physical as well as mental stress etc. progress into various disorders like Obesity, Diabetes, Hypertension, Heart diseases, Cancer, Stroke, Skin problems, Immune mediated diseases etc. In Chaturmas, rainy season is already prone for various air born, water born and food borne diseases. Agni status (digestive and metabolic fire) is not better in this season. To overcome all these problems, it is necessary to follow Chaturmas which helps to promote physical, spiritual, mental plus social health.

\section{Science behind Chaturmas Upvas:}

Maharshi Kashyap mentioned that "Aaarogyam Bhojanadhinam" means health is product of healthy food. ${ }^{[7]}$ Aacharya Charak enlightened that 'Ekashana Bho- 
jan Sukhaparinamkaranam', means taking meal once in a day gives beneficial effects in all aspects. ${ }^{[8]}$ Hence variety, quantity, quality and frequency of eating should be according to Prikriti, Desha, Kala, Ritu, Agni status, as well as Aharvidhivisheshyatan (die-tic rules) ${ }^{[9]}$ however maximum humans are careless regarding this which results in variety of diseases.

Scientific Upvasa helps in complete normal assimilation, abnormal metabolites digestion or excretion, elimination of harmful substances from cellular or minute level, enhance metabolism, and promote cleansing of body. It helps in reduction of body fat and mass, give complete physical, physiological and sensory rest, improve and strengthens immune system, repair and rejuvenates the whole body system, prevents harmful changes in vital organs and improve their functional efficiency, helps to improve the strength of cardiovascular system and reduces incidence of myocardial infraction, fasting awakens the mind, develops inner tranquility, helps to prevent metabolic and lifestyle disorders etc. ${ }^{[10]}$ Thus Chaturmas Upvas in proper way improves health at all level.

It is assumed that Chaturmas is the period of rest of God. During this period evils becomes more active hence malicious frequencies reach to the earth. It harasses the humans therefore some peoples are disturbed physically as well as mentally to some extent. Protection from such evil frequencies is possible by Satvic practices like eating of Satvic food, Atma Chintan, Parmatma Chintan, and worship to God etc.

\section{DISCUSSION}

Chaturmas fasting initially may cause weakness, headache, disturbed sleep, acidity, giddiness etc. in Pitta as well as Vata Prikriti humans and subsides after seven days. In such condition pure suitable fruit can be taken after proper hunger sensation. Kapha Prikriti persons can easily go for fasting. Humans suffering from disease in which fasting is not suitable should take advice from their family doctor.

Healthy, Satvic, easily digestible, natural food is advised at once during Chaturmas. Due to restriction on the habit of frequent eating, food is digested completely to form best final product for our body and mind.
Various abnormal byproducts (Ama) from minute level will be processed or excreted from our body and helps to prevent the disease prone condition.

During Chaturmas Atmachintan, Parmatmachintan, worship to God, Chanting etc. are practiced. It helps to uplift the spiritual health. Best physical and spiritual health contributes in mental as well as social health. The Jalamahabhuta as well as Kleda in environment is elevated in Chaturmas. It is favorable for survival of various organisms hence infectious diseases are very common. If we use fresh cooked warm food once for eating and boiled drinking water, then Jalamahabhuta as well as Kleda in our body will be automatically balanced and prone condition for infection is prevented.

In Chaturmas various festivals are celebrated like Durga Puja, Navratri, Sharad Purnima, Dashehara. Dipavali etc. which brings close to relatives, friends, society members. It helps to develop a healthier attachment as well as contributes to improve social health.

After end of Chaturmas one should not start excessive eating, frequent eating, fast food, fried food, unhealthy practices etc. because it may cause diseases hence try to eat healthy easy digestible food once or twice only. If someone who is not able to keep lengthy Chaturmas Upvas may be benefited with intermittent Upvas designed in various rituals by sages.

\section{CONCLUSION}

Chaturmas Upvas is training for living with control on mind as well as senses and continuing awakening early in morning, Atmachintan, Parmatma Chintan, worship, Yoga, Pranayam, minimum required frequency of healthy food intake etc. which result in health at all level.

\section{REFERENCES}

1. Sushruta. In: Vaidya Yadavji Trikamji Acharaya, Narayan Ram Acharaya, editors. Sushruta Samhita, Varanasi: Chaukhambha Orientalia; 2007. Su.15/41

2. Agnivesha, Charaka, Dridhabala, Charaka samhita,edited by Vaidya Yadavaji Trikamji Aacharya, $2^{\text {nd }}$ edition, Chaukhamba Sanskrit Sansthan, Varanasi, 1990; Su.1/15 
3. https://en.wikipedia.org/wiki/Chaturmas.

4. https://www.speakingtree.in/blog/meaning-of-upvaasor-fasting

5. Fasting Therapy/Ministry of AYUSH/GOI (ayush.gov.in /about-the-systems / naturopathy/ techniques-and-benefits-different-modalities-naturopathy / fasting-therapy)

6. https://www.sanatan.org/en/a/303.html

7. Kashyap Samhita, Vridhajivkiya tantra, written by shree Satyapal bhishgaacharya, $9^{\text {th }}$ edition, Chaukhamba Sanskrit Sansthan, Varanasi, 2004; Khila sthana 5/9

8. Agnivesha, Charaka, Dridhabala, Charaka samhita, edited by Vaidya Yadavaji Trikamji Aacharya, $2^{\text {nd }}$ edition, Chaukhamba Sanskrit Sansthan, Varanasi, 1990; Su.25/40

9. Agnivesha, Charaka, Dridhabala, Charaka samhita, edited by Vaidya Yadavaji Trikamji Aacharya, $2^{\text {nd }}$ edition, Chaukhamba Sanskrit Sansthan, Varanasi, 1990; Chi.1/21

10. The complete handbook of "Nature Cure" by Dr. H.K. Bakhru, $5^{\text {th }}$ revised edition, JAICO publishing house, chapter no. 2./P.13

\section{Source of Support: Nil \\ Conflict of Interest: None Declared}

How to cite this URL: Jaybhaye Sulakshana et al: Chaturmas Upavas (Fasting) - A Scientific Review. International Ayurvedic Medical Journal \{online\} 2020 \{cited September, 2020\} Available from: http://www.iamj.in/posts/images/upload/4493 4496.pdf 